Florida International University FIU Digital Commons

$11-6-2012$

\title{
Centered Fluidity and the Horizons of Continuity in Djuna Barnes' Nightwood
}

Maria C. Sepulveda

Florida International University, msepu004@fiu.edu

DOI: $10.25148 /$ etd.FI12112802

Follow this and additional works at: https://digitalcommons.fiu.edu/etd

\section{Recommended Citation}

Sepulveda, Maria C., "Centered Fluidity and the Horizons of Continuity in Djuna Barnes' Nightwood" (2012). FIU Electronic Theses and Dissertations. 746.

https://digitalcommons.fiu.edu/etd/746 


\title{
FLORIDA INTERNATIONAL UNIVERSITY
}

Miami, Florida

\section{CENTERED FLUIDITY AND THE HORIZONS OF CONTINUITY IN DJUNA BARNES' NIGHTWOOD}

\author{
A thesis submitted in partial fulfillment of \\ the requirements for the degree of \\ MASTER OF ARTS \\ in \\ ENGLISH \\ by
}

Maria Sepulveda 
To: Dean Kenneth G. Furton

College of Arts and Sciences

This thesis, written by Maria Sepulveda, and entitled Centered Fluidity and the Horizons of Continuity in Djuna Barnes' Nightwood, having been approved in respect to style and intellectual content, is referred to you for judgment.

We have read this thesis and recommend that it be approved.

Phillip Marcus

Maneck Daruwala

Ana Luszczynska, Major Professor

Date of Defense: November 6, 2012

The thesis of Maria Sepulveda is approved.

Dean Kenneth G. Furton
College of Arts and Sciences

Dean Lakshmi N. Reddi University Graduate School

Florida International University, 2012 


\section{ACKNOWLEDGMENTS}

I would like to thank Professor Phillip L. Marcus for the undeniable amount of patience and imparting in me an undying love of literature and teaching. I teach because of you, and will continue to show students that all parts of the elephant are to be equally acknowledged and studied. I follow my bliss only because you showed me the way! I cannot thank Dr. Ana Luszczynska enough for painstakingly editing this thesis and helping me "eff" the ineffable. You are singularly responsible for blurring my coherent thoughts and necessarily decentralizing my existence no matter how hard I tried to live in blissful ignorance. Your ideas and your enthusiasm are contagious and this paper would not have been written without your Ana-ness. I wish to also thank Dr. Maneck Daruwala (I may never to be able to call you "Maneck") for your saintly patience and never-ending good disposition. You are a true close-reader of text and a woman I highly admire. I can only hope to read and teach half as well as you have shown me. Thank you as well to Dr. James Sutton and Dr. Asher Milbauer for always having time for guidance and a smile. Both of you have shown me that academia, administration, and a wonderful sense of humor are all quite possible! To my family and friends, thank you for allowing me to go on a physical and mental hiatus from your lives these past couple of years. Academia seems to take a toll on your social and family time, and I'm incredibly grateful you were all waiting for me at the finish line. It's great to be here! 


\section{ABSTRACT OF THE THESIS \\ CENTERED FLUIDITY AND THE HORIZONS OF CONTINUITY IN \\ DJUNA BARNES' NIGHTWOOD \\ by}

Maria Sepulveda

Florida International University, 2012

Miami, Florida

Professor Ana Luszczynska, Major Professor

Modern writers like Djuna Barnes allow for the post-modern fluidity and explosion of sex and gender without finalizing either in a fixed form. Whereas the classical, archetypal androgyne is made up of two halves, one man and one woman; the deconstructed androgynous figure is not constituted of oppositional terms which would reflect an essential and unimpeachable truth. I reveal the way Djuna Barnes' Nightwood not only thematizes the fluid androgyne, but also cleverly verbalizes David Wood's perpetual and un-dischargable "debt" to extra-discursivity while poetically critiquing gender "appropriateness," societal constraints, and the constitution of identity. Barnes presents a decentralized, ungrounded and non-prescribed world in Nightwood not only through her cross-dressing and androgynous characters, but also in her poetics, her assertion of the open-ended quality of language, and a strong imperative to negotiate our physical existence in a world of fluid gender and sexual boundaries 


\section{TABLE OF CONTENTS}

CHAPTER

PAGE

I. INTRODUCTION TO FLUID ANDROGYNY AND NIGHTWOOD ...........1

David Wood and Deconstruction......................................................

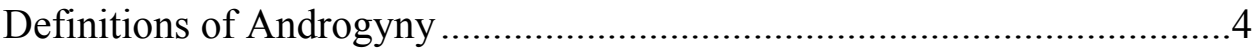

Virginia Woolf and Androgyny .............................................................

Feminist Critique ..........................................................................6

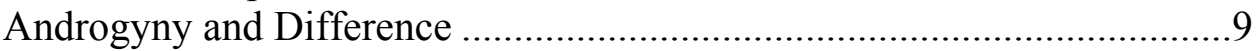

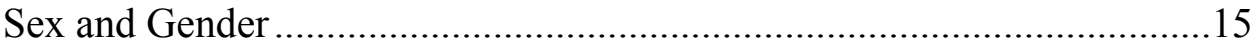

II. CHAPTER II: CLOSE READINGS AND THEORETICAL ANALYSIS ....17

Robin Vote ...................................................................................... 19

Jansenism: Free Will and God's Salvation ..............................................24

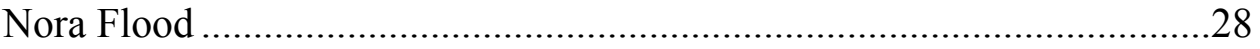

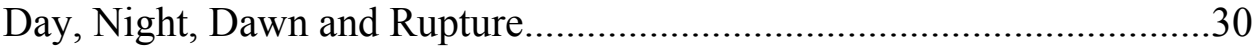

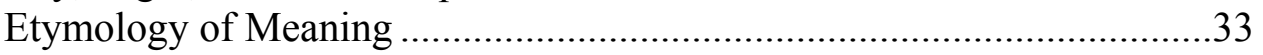

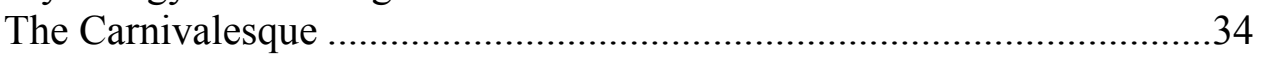

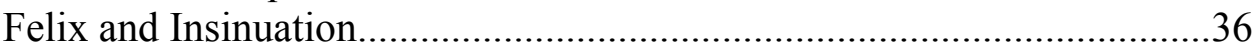

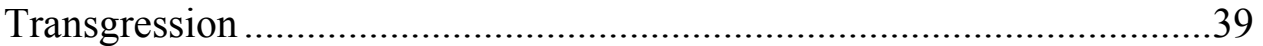

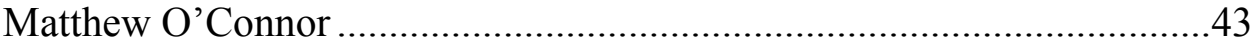

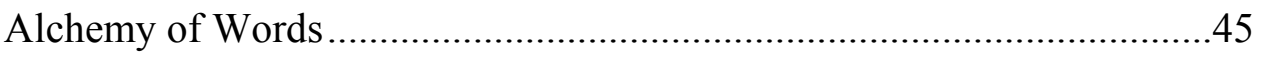

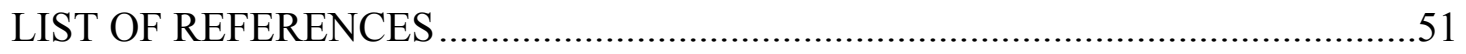

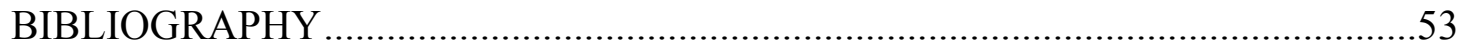




\section{CHAPTER I: INTRODUCTION TO FLUID ANDROGYNY AND NIGHTWOOD}

"I can't get the book accepted anywhere, it is now at the fifth publisher. ... ...they say it is not a novel; that there is no continuity of life in it, only high spots and poetry - that I do not give anyone an idea what the persons wore, ate or how they opened and closed doors,

how they earned a living or how they took of their shoes and put on their hats. God knows I don't."

\section{Djuna Barnes}

\section{In The Step Back: Ethics and Politics After Deconstruction, David Wood asserts}

that we have a continuing "debt to the unthematized," that is everything that cannot be explained with our everyday rhetoric. "[T]he impossibility of finally discharging that debt," he writes, "is one of the central motifs of deconstruction" (2). Wood's work is rooted in the deconstructive notion that final, fully present meaning is unachievable and that meaning is multiple and contextual - we can only get answers to the questions we ask which are always rooted within individual conceptual frames. Wood also reminds us that "agency is grounded in receptivity" and that this detail is easily forgotten. Our knowledge is rooted in our experience and our language, so "ungrounding" or "decentralizing" our existence rather than following a pre-existing prescribed path is troubling for some; and denying difference while accepting differance ${ }^{2}$ causes us a considerable amount distress. In requires that we step outside the prescribed or already meaningful world we navigate and create new rules and possibilities while doubting what is considered intrinsic, natural, or universal. For instance, gender seems to be uncategorizable as a socio-normative rule or a human biological predisposition. We only understand it based on our experience as a woman or man and have tremendous trouble

\footnotetext{
${ }^{1}$ Djuna Barnes' letter to Emily Coleman qtd. in Cheryl J. Plumb's introduction to an annotated version of Nightwood

${ }^{2}$ Differance is a term coined by Jacques Derrida playing on the fact that the French word differance means both, "to defer" and to "differ."
} 
detaching ourselves from this duality. Post-modern theory and modern writers, like Djuna Barnes allow for the fluidity and explosion of sex and gender without finalizing either one into a stable form. Miss Barnes also joins the gender versus sex debate by allowing her unlikely heroine, Robin Vote, to flow within sexuality and genders while attempting to disrupt entrenched ideas of what these might entail. These ideas can only be explored, however, if we keep questioning, moving and "affirm[ing] the necessity of, ambiguity, incompleteness, repetition, negotiation, and contingency" (Wood 4) in order to internalize these as positive words in our discourse and thus our world.

One of the major determiners of our identity is our alleged empirical existence as man or woman, and this difference is in turn a strong determinant of our role in society. So how do we deal then with gender ambiguity or incompleteness without existentialist angst? Should we, if that is the case, embrace existential angst? These questions are explored in Djuna Barnes' Nightwood ${ }^{3}$ published in 1937 - a novel that not only thematizes androgyny and gender ambiguity, but also cleverly verbalizes David Wood's perpetual and un-dischargable "debt," while poetically critiquing gender "appropriateness," societal constraints, and the constitution of identity. We must, that is, acknowledge the importance of questioning the natural designation of our lives and the corresponding systems we follow. My thesis reveals the ways Barnes presents a decentralized, ungrounded and non-prescribed world not only through her cross-dressing and androgynous characters, but also in her poetics, her assertion of the open-ended

\footnotetext{
${ }^{3}$ Cheryl Plumb explains that Nightwood went through several titles including "Bow Down" and "Anatomy of the Night". Some credit the title to T.S. Eliot but Plumb asserts that on June $23^{\text {rd }}, 1935$ Barnes announced the novel as Nightwood. "Only later in October 1936 did Barnes write [Emily] Coleman [, dear friend and collaborate reader,] of her discovery that the title was Thelma's name: 'Night T. Wood—low, thought of it the other day. Very odd"” (viii-ix).
} 
quality of language, and a strong imperative to negotiate our physical existence in an ungrounded world of blurring gender boundaries.

Nightwood was written well before deconstruction became a source of debate in the 1960s when Derrida famously stated in Of Grammatology that there was nothing outside of the text ${ }^{4}$. Nightwood has been virtually left out of deconstructive critique and this paper is also an attempt to partially fill in that gap. In other words, if there is nothing outside of the text then everything means in relation to another text. Do we, if that is the case, know what a man is because it is not a woman? And how is gender defined if there is nothing to compare it to?

Nightwood also has a strong autobiographical connection including Barnes' long term affair with Thelma Woods, and the author's rejection of categories such as "lesbian" and allegedly "woman." The novel is an exercise in textual ambiguity, psychological and physical incompleteness, and the quintessential androgynous Robin Vote who lives in a liminal world, always in flux, never steady and never arriving. Her name is rich in interpretive possibilities - the robin is a bird, always in motion and practically homeless. Much like her last name implies, Robin voted and made a choice to not be incarcerated by feminine expectations. Her name is also an imperative or call to action: Robin go ahead and vote. In the story, her lovers want her to choose between them, and her abandoned husband aches to have her near his family and her child. Additionally, Robin is a masculine and feminine name with androgynous implications of its own.

We can begin by examining the appeal of androgyny, its prevalence in modern art and culture, and its classical definitions. In Toward a Recognition of Androgyny,

\footnotetext{
${ }^{4}$ This statement has been widely misinterpreted as meaning outside of the written text. What Derrida meant was that there is nothing outside of the text because everything is, in fact, a text.
} 
Heilbrun tells us that androgyny seeks a "reconciliation of the sexes" and a solid departure from the oppressive and absolute "confines of the appropriate" (x). The word androgyny comes from the Greek "andro (male) and gyn (female)" and Heilbrun explains that it "defines a condition under which the characteristics of the sexes, and the human impulses expressed by men and women, are not rigidly assigned" (x). In other words it allows us to let go of what we know empirically as woman and man, and free ourselves from these arguably socially assigned genders and sexual categories. However, these theories presuppose a grounding, discursive understanding of gender insofar as their classical, metaphysical ${ }^{5}$ definitions are concerned. That is, even the definition of the word, as Heilbrun explains, is made up of binaries which inevitably bound and oppress movement and fluidity. Derridean and post-modern thinking renders all binaries subject to interrogation by suggesting that significance or meaning come from differance and that the words "woman" and "man" have no absolute, final meaning as free-standing ideas. It also understands wholeness and completeness as confining and thus ultimately oppressive and tyrannical. The analysis that follows is derived largely from this post-modern notion although the novel's language will prove it almost impossible to avoid the duality of gender. Nevertheless, Barnes' poetics continually assert the impossibility of fully present meaning and rather understands the "alchemy" of words. "We should look well around," Barnes writes, "doubting everything seen" because we have a word for it and not its "true" substance (72). Namely, Barnes engages in a discourse where meaning is contextual and literal language is thus limited in its signification.

\footnotetext{
${ }^{5}$ Western metaphysical thought, i.e., classical philosophy.
} 
Historically speaking, a surge of androgynous literary symbolism came about in modern literature and canonized writers like Joyce, Woolf, Eliot, Barnes, and Hemingway make androgyny a central organizing concept. In the late 1920s and early 1930s, Virginia Woolf's A Room of One's Own served as a catalyst for androgynous critique: "But the sight of the two people getting into the taxi and the satisfaction it gave me made me also ask whether there are two sexes in the mind corresponding to the two sexes in the body, and whether they also require to be united in order to get complete satisfaction and happiness..." (139). She then famously quotes Samuel Taylor Coleridge and declares that a "great mind must be androgynous" (A Room 139), much like the sight of the man and woman coalescing in to the taxi. Woolf theorizes that it is only after this "fusion" happens that our minds could be "fully fertilized" to engender, create, and use "all its faculties" (139). Mirroring Joyce's "womanly man" in Ulysses, Woolf asserts in A Room that "It is fatal to be a man or woman pure and simple; one must be woman-manly or man-womanly" (103). She explains that "[s]ome collaboration has to take place in the mind between the woman and the man before the act of creation can be accomplished" ( $A$ Room 103). Woolf's androgynous notions mirror Heilbrun's definition of androgyny insofar as they define and constitute androgyny as a "fusion" of the male and female psyche without taking into consideration the essentializing of a new third sex, a presupposition of unity, and a reliance on rather than undermining of the binary. American feminist critic Elaine Showalter accuses Virginia Woolf of using androgyny as a way to distance herself from any kind of strong feminist stand. Showalter argues that Woolf was uncomfortable with the idea of feminism and in A Literature of Their Own states that, "[Woolf] would like to possess a more serene and thus more 
comfortable consciousness" (287) ergo her apparent personal detachment from pieces like $A$ Room of One's Own. Toril Moi critiques Showalter's “impatient" reading of Woolf in Sexual/Textual Politics and believes Showalter "is motivated much more by [the essay's] formal and stylistic features than by the ideas she extrapolates as its contents" (3). I find Woolf's alleged rejection of feminism relevant insofar as it mirrors Barnes' rejection of "lesbian" as an identifying category while asserting her love for Thelma. Susana Martin's concurs and states that this was Barnes' way to contest gender categories since she never denied her affair with Thelma and in fact is famous for publicly declaring that, "I am not a lesbian. I just loved Thelma" (109). Martin cites Judith Butler's gender theories in her analysis and explains that "Barnes is known to have accepted the term 'lesbian' when she thought it was being used to indicate she had affairs with women. But she was uncomfortable with the identity category in general, perhaps, because like Butler, she recognized that 'identity categories tend to be instruments of regulatory regimes"' (110). Much like Woolf and more contemporarily Helene Cixous, refused to be labeled as feminists, Djuna Barnes refused to be bound as a lesbian along with the inevitable social implications the term carried with its "otherness." Andrew Field mentions that "in part, it was surely her intense individualism that would not permit her to conscript herself to any movement" (53). Unfortunately, any category constituting human identity clearly demarcates a boundary and inevitably labels some group as "others" since categories can only exist based on one central, accepted, and "natural" norm. We do not have a "human" category, for instance, because being human is our accepted natural, inherent and unquestionable state of being - the center. It is in this vein that Simone de Beauvoir's The Second Sex explains that whatever attempts to pass itself as "natural" ought to be 
interrogated. Tina Chanter states in Gender Theories, that "such a point of view is, by default, taken to be the universal position" (9) or unimpeachable truth, and only recently has the theoretical world begun to challenge the state of gender categories with the advent of queer theory.

When A Room of One's Own was published, Woolf was simultaneously working on Orlando - a novel whose protagonist is a time-traveling prince who wakes up one day as a woman while the trumpets clamored "Truth! Truth! Truth!” (102). Woolf dismissed Orlando as a joke and Nancy Toppin Bazin decided not to include it in Virginia Woolf and the Androgynous Vision published in 1973. Yet the 1928 novel's rich language not only mimics its Renaissance setting, but its thorough disregard for chronological temporality and any type of gender "appropriateness" make it a classical example of androgyny and the unconventional aesthetics of modernism:

The difference between the sexes is, happily, one of great profundity. Clothes are but a symbol of something hid deep beneath. It was a change in Orlando herself that dictated her choice of a woman's dress and of a woman's sex. And perhaps in this she was only expressing rather more openly than usual - openness indeed was the soul of her nature - something that happens to most people without being thus plainly expressed. For here again, we come to a dilemma. Different though the sexes are, they inherently intermix. In every human being a vacillation from one sex to the other takes place, and often it is only the clothes that keep the male or female likeness, while underneath the sex is the very opposite of what is above (Orlando 139). 
Although the passage reinscribes androgyny as constituted from a closed male and female form, it is relevant to this analysis insofar as it clearly asserts that gender is not just a physical trait. The passage also traces the basic concepts of androgyny back to modernism. Orlando's soul is open, allegedly endless and androgynous. What exactly Woolf means by "soul" is unknown, but for the purposes of my thesis I theorize that Orlando's soul is necessarily outside of gender and thus androgynous by its lack of sexual duality. Woolf presents the intermixing of the sexes as a "dilemma" and proposes a "vacillation" from one sex to the other much like Matthew O'Connor does in Nightwood. I will show how Barnes manages to depict this classical definition of androgyny in O'Connor as well as the fluid androgyne in Robin. That is to say, O'Connor vacillates between man and woman emulating Heilbrun's male plus female androgyne definition, while Robin flows unencapsulated by the duality of male and female epitomizing Kari Weil's transcendent androgyne whose wholeness never presupposes a perfect center or universal femininity or masculinity (Weil 148).

Linear temporality is not something we see much of in modern literature. The irregular and often unpredictable shifts in time are used frequently in Nightwood and Orlando. Caroll Smith-Rosenberg calls Orlando a "trickster par excellence" and mentions that she fluidly moves across time within incredible and unreal settings. "Creating her/himself out of fancy, farce, and finery, she tricks us into abandoning all that we know: that sex is unchangeable... time confining and patriarchy invincible" (291). The novel truly makes the reader wonder the what-ifs of a world of gender fluidity and wherein androgyny is a pragmatic ideal that may be physically and emotionally achieved. The recognition and internalizing of androgyny, as Virginia Woolf put it in A Room, will yield 
a more creative, "porous" and "incandescent" mind beyond the back and forth of any kind of power struggle between the two sexes.

Gender along with its implications concerning identity, feminism, and the modern literary canon has been scrutinized by countless critics crossing over to several academic fields including sociology, anthropology, and of course literature. Critics like Toril Moi, Hélène Cixous, Kari Weil and bell hooks have written endlessly about language, race, feminism and identity. Lisa Rado and Hoeveler published books on androgynous literary critique in romantic and modern literature. Further, Carolyn Heilbrun's groundbreaking work established a solid definition of androgyny and paved the way for this analysis along with Weils' examination of language and difference. Consequently, my thesis will scrutinize gender within the framework of post-modern critique, modern literature, and in particular Djuna Barnes' Nightwood with the understanding that the fluidity of the androgynous device cannot be encapsulated into one "whole" because such an encapsulation would implicitly recreate the absolute being that only highlights the two binaries it is attempting to debunk. I argue that the androgynous mind is "porous" and "incandescent" (Woolf, A Room 56) because of its fluid, non-confining state, allowing it to navigate extra-discursively and thus attain a kind of "synthetic wholeness" (Weil 33) needed for what David Wood calls "operational thinking" within the conceptualized (3). In other words, the androgyne allows for "its alternation of male to female...reflect[ing] the totality that it never encompasses in the present" (Weil 33). The androgyne, much like deconstructive language, posits and withdraws meaning and it defines wholeness without the fixidity the term may imply. 
Djuna Barnes ${ }^{6}$ thought of Nightwood as her "life with Thelma" who was the inspiration for Robin. In the introduction to a 1962 annotated version of Nightwood ${ }^{7}$, Cheryl J. Plumb calls Djuna and Thelma's nine-year relationship "idyllic and destructive" (vii) very much emulating the interminable list of paradoxes and irreconcilable binaries within the novel. The doctor is a "divine idiot and a wise man" (35), couples are "together and alone" and Robin seems "newly ancient" (45). These irreconcilable binaries present a significant starting point for analyzing Barnes' text within the framework of deconstruction and its application on gender and identity. Because Barnes' life is also a text, it will be treated as such for the purpose of this analysis. A reading of a manner in which her biographical narrative intersects with Nightwood will be explained.

In Androgyny and the Denial of Difference, Kari Weil quotes Donna Haraway and explains that "[Irony] is about contradictions that do not resolve into larger wholes, even dialectically, about the tension of holding incompatible things together because both or all are necessary and true. Irony is about humor and serious play"” (161-161). This kind of irony cannot be "defined in terms of opposition, but only in terms of unstable difference" asking the reader to take pleasure in the blurring and corresponding explosion of boundaries (Weil 160 - 161) - an act arguably depicted by Doctor Matthew "Mighty" O’Connor and Robin Vote in Nightwood. Both characters blur gender boundaries and insinuate the distortion of a closed gender form. O'Connor is a self-proclaimed charlatan,

\footnotetext{
${ }^{6}$ In The Life and Times of Djuna Barnes, Andrew Field calls Miss Barnes the "unluckiest" of all modern writers. He details her numerous amorous affairs with men and women and the devastating way her father sexually offered Barnes to an older man. She was "given," Field explains, rather than "seduced or raped" (43) ostensibly taken all human agency from Barnes as a woman, daughter and child. It is no wonder than she is known to believe that humanity was entirely damned with women being terrible but men being absolutely worse.

${ }^{7}$ All references to Nightwood text will be taken from Cheryl Plumb's edition, Nightwood: The Original Version and Related Drafts.
} 
unlicensed medical practitioner, and the one constant orator and paradoxical truth-teller: “...the reason he knows everything," explains the Doctor speaking of himself as he often does, "is because he's been everywhere at the wrong time and has now become anonymous" (89). Barnes tells us repeatedly of O'Connor's vacillation from man to woman: He think he's a bride when listening to music, he sleeps in a flannel gown fully made up wearing a golden wig and "he's been everywhere" - much like Orlando, the time travelling prince vacillating between sexes. O'Connor calls himself "anonymous" because he is arguably unrecognizable in our psyche and thus in society, living outside established designations and corresponding genders. We cannot visualize the modern androgyne in any other way. Only the hermaphrodite with male and female genitals attempts to metaphysically crystallize the androgyne, which "has often been considered to be an archetype or a universal fantasy. More specifically, psychological analysis equates androgyny with a repressed desire to return to the imaginary wholeness and selfsufficiency associated with the pre-Oedipal phase before sexual difference" (Weil 3). We cannot think of androgyny is physical terms, however, because this over-simplifies and deemphasizes the importance of the concept and contradicts the notion of fluidity. Weil explains that " $[\mathrm{t}]$ he androgyne is assumed to transcend, if not to exist prior to, the terms that define and constitute it, specifically the terms characterizing male and female. Defined through this distinction, it reinscribes the sexual difference that it seeks to efface or to dissolve into a synthetic wholeness" (33). This "difference" must be understood as just difference and not difference from other opposite terms which would inevitably create duality and binaries. The androgyne is radically prior to the male and female parts that make up its fluid structure; as deconstruction necessarily avoids definition so does 
the androgyne as an event and ideal. Put differently, deconstruction aims to be practiced as an action and imperative. We simply cannot not do it. The androgyne cannot help but be which is ostensibly the reason Barnes talks of "sensations" in Nightwood. In other words, if meaning comes from differance, from the infinite difference and deferring of signification, then the androgyne must necessarily be within that space and that trace that constitutes differance. As Barnes mentions in the novel, it is a "sensation of a thought" (69). In other words, as soon as we identify it as an actual thought, as an actual thing or event within our conscious discourse, it becomes fixed, stable and thus unable to flow.

In The Modern Androgyne Lisa Rado explores "the almost hermaphroditic nature of the concept of androgyny in modernist usage" and highlights the ways "male authors... represent their creative minds as if they are characterized by a balance of sexually charged energies, fueling their artistic impulses with oppositional tensions" thus plainly reinscribing a binary (12). She quotes an article by novelist Dorothy Richardson where “Like Virginia Woolf, in a Room of One's Own, Richardson points to the real threats that patriarchy still holds for the modern intellectual woman" (12). Rado goes on to question the ways a modern woman was to define herself as a writer and artist given the continual pressure to succeed as domestic partners, mothers, and ultimately muses (12). Djuna Barnes defies these normative, seemingly socially enforced ideals and reclaims a Foucauldian kind of power in Nightwood where characters create their realities by rejecting social norms and inventing their world and thus their power. That is to say, Foucault insisted on an "omnipresence of power; not because it has the privilege of consolidating everything under its invincible unity, but because it is produced from one moment to the next, at every point, or rather in every relation from one point to another" 
(History 93). Power is not fixed and so it can be moved, created and manipulated. Much like power is in constant flux, so is the androgyne in Nightwood. Barnes, however, gave the androgynous Robin power by marrying her to Felix. Although Felix and his marriage to Robin Vote were criticized as unnecessary and superfluous, Barnes “defended Felix's role justifying it in terms of Robin's reality" which Cheryl Plumb explains could also be Barnes' reality (xvii). In a letter to her friend Emily Coleman, Barnes writes:

Robins marriage to Felix is necessary to the book for this reason (which you can not know, not having lived with a woman having loved her and yet circulated in public with that public aware of it) that people always say, 'Well of course those two women would never have been in love with each other if they had been normal, if any man had slept with them, if they have been well f----- and had born a child (xviii).

According to Plumb, this showed the author was not impervious to public opinion. However, "Barnes had also come to have a sense of [Nightwood's] structure and unity that differed from the conventions of the traditional realistic novel" (Plumb xviii). I theorize that Barnes intended to refute the male/female duality as well as universal ideals of sex and gender with Robin's marriage and motherhood. For example, she arguably attempted to illustrate that maternal instincts and gender roles were not universal by having Robin give birth to Guido and immediately reject her role as caretaker and wife. Barnes tells us that Robin “...was gracious and yet fading, like an old statue in a garden, that symbolizes the weather through which it has endured, and is not so much the work of a man as the work of wind and rain and the herd of the seasons, and though formed in man's image, is a figure of doom." That is to say that Robin was "gracious" and 
attempted to be the woman that was arguably imposed on her, but this façade or this performance as Butler would say slowly faded. In comparing Robin to an old statue in the garden, Barnes places this figure - this stable, static statue within what is considered natural and inherent. The grass, the weather and the seasons - or nature - have worn down the man-made statue and Robin's attempt to fill the role of femininity and womanhood. The weather, arguably socially imposed rules and fixidity, slowly wear it Robin down. Barnes says she is made is man's image which I argue is another way of highlighting her androgyny and eventually leading to her "doom" because our discourse simply cannot process her existence.

Because the sex versus gender debate is relevant to this analysis, it is important to note that, "[t]o argue that there are naturally two and only two sexes, male and female, and that the traits of these sexes are mutually exclusive, is to mirror the heterosexists beliefs of the dominant, western, advanced, late-capitalist era, and to construe the function of sex to be teleologically circumscribed by the end of reproduction" (Chanters 6). In other words, with the birth of Guido - Robin and Felix's son - Barnes joins the sex and gender discourse by allowing Robin's sexuality and genderlessness to exist after the supposed ultimate goal of sexuality is achieved. That is, after Robin gives birth to her son.

Arguably, Miss Barnes' decision to include Robin's marriage in Nightwood is about power and autonomy. Much like David Wood's notion that we can only take responsibility for what we know based on a certain conceptual frame, Michael Foucault asserts that truth is created in discourse and that our reality is relational and culturally dictated. Power is not "monolithic" (Chanter 57) nor does it come from one specific 
source. All decisions and claims of morality, for that matter, are relative. Foucault believed that power is everywhere and it comes from everyone: “...power is not an institution, and not a structure; neither is it certain strength we are endowed with; it is the name that one attributes to a complex strategical situation in a particular society" (History of Sexuality 93). Because we do not have a strong referent for the androgyne in society, that is a physical body that possibly represents it, its power must be accessed and disseminated extra-discursively and/or poetically. The hermaphrodite, as stated above "haunts" the androgyne but fails to correctly depict it and unfortunately stays within a very limited understanding of what we know of gender and sexuality. That is to say, visualizing the androgyne as hermaphroditic is simply reductive insofar as it crystallizes and essentializes a notion that is meant as an event in motion.

There is an underlying anxiety when speaking of modernism and gender - both terms may seem impalpable and ambiguous albeit in theoretical circles, these terms are embraced as representing freedom and possibility. However, gray areas tend make us inevitably uncomfortable, and the androgynous figure, albeit praised as the ideal beauty and portrayed as a primordial form radically prior to either sex in ancient texts, has the same effect. The gender versus sex controversy provides no solid ground and it mimics the old chicken and the egg dilemma. Does the physical sex of a person posit its unquestionable gender or does the behavior of either gender justify its sex and designation? That is to say, can gender precede sex? Some critics argue that by reversing the conventional idea that sex precedes gender, we open up a space to discuss sex as fluid and unstable instead of a solid notion constituted of genitalia (Chanters 5). The most prevalent theory is that sex - our physical and biological traits - is used to materialize 
and crystallize the already existing socio-normative rules of gender. Sex usually exerts a sort of "authority" over gender and great significance is placed on the allegedly irrefutable facts of the body. That is to say, we are much quicker to categorize someone as "woman" or "man" based on their genitalia than based on their gender or societal behavior. However, biology and science are always understood from a certain conceptual frame and the idea of "naturalness" can be challenged if we remove the ground where these ideas are anchored (Chanter 44). We can thus understand and possibly challenge alleged unimpeachable facts and truths when everything we based these truths on is no longer stable.

In (En)Gendering Modernism, Suzette Henke discusses the problematic idea of defining gender and modernism: “...gender is neither a biological category nor a philosophical essence, but a fluid and indeterminate subject position defined by competing discursive practices" (327). She quotes Chris Weedon and mentions that "humanist discourses 'presuppose an essence at the heart of the individual which is unique, fixed and coherent,"' and differentiates this from the subjectivity of postmodernism which is "constantly being reconstituted in discourse each time we think or speak" (327). Attempting to classify gender as a final form may thus be problematic. Post-modern critique allows for an androgynous reading without the essentializing of the androgyne into a perfect anything or constituting it from oppositional parts which ultimately cannot exist extra-discursively. That is to say, they cannot exist within our discourse because as previously mentioned, once that "sensation of a thought" becomes an actual, rigid thought, it is no longer in fluid movement. Moreover, the aesthetics of modernism seem like a basic canvas for post-modern analyses: the plot ambiguities, its 
unorthodox temporality, and the general chaos of high modernism in particular seem to allow for strong deconstructive readings. Henke believes a redefinition of modernism is needed since the ways it has generally been understood posit a logocentric and phallocentric tradition. She maintains that what is needed is rather to think of modernism as "a period of transformation fed by a multiplicity of genres and voices and constructed by a series of experimental texts that mutually enhance an intertextual discourse in a global community" (326). Henke wonders if modernism as we have known it ever existed, or if perhaps it never ended.

\section{CHAPTER II: CLOSE READINGS AND THEORETICAL ANALYSIS}

"Yes, I have only one language; it is not mine."

\section{Jacques Derrida}

If we think of gender in the metaphysical world, it is definitive and then we, as receptors have absolutely no agency in the matter. World presents "man" and "woman" as perfect, enclosed forms and we follow and represent them never having a choice. In contrast, deconstruction asks that we actively create gender by removing those closed "forms" thereby providing a space for negotiation, exploration, fluidity, and freedom. Whereas the classical, archetypal androgyne is made up of two halves, one male and one woman, the deconstructed androgynous figure is not constituted by oppositional parts which would reflect an essential and unimpeachable truth. Barnes thematizes the idea in Nightwood with an ache for balance which I propose we think of as centered fluidity. Her prose indicates a constant struggle to move teleologically toward the unknown, that is, the horizons of continuity, while staying in motion and yet paradoxically centered and 
synthetically balanced. The synthetic balance emulates Weil's synthetic wholeness in that in presupposes a kind of harmonious loop and forward teleological without arrival or rigidity. The fluid/synthetic balance in Barnes' poetics, I argue is her sublime approach to the androgynous mind, since the androgyne can only exist outside of discourse in this kind of pseudo-wholeness. For instance, one character that personifies this in Nightwood is Nora - whose "savage and refined" nature, Barnes tells us, was in perfect equilibrium. Nora has been called patriarchal by several critics and seems to be represented by phallogocentric dualities like day, logic, boundaries, and stability. Nora was a Christian; "she believed the word" (47) - arguably a reference to the Holy Scriptures as well as language and text. Barnes describes her presence as being and absent all at once arguably struggling between the metaphysical and the deconstructive:

There is a gap in "world pain" through which the singular falls continually and forever; a body falling in observable space, deprived of the privacy of disappearance; as if privacy, moving relentlessly away, by the very sustaining power of its withdrawal kept the body eternally moving downward, but in one place, and perpetually before the eye. Such a singular was Nora. There was some derangement in her equilibrium that kept her immune to her own descent (47). "Gap" inevitably provokes trace and vestige and deconstructively speaking, creates meaning ${ }^{8}$. There is emphasis on the actual physical body and the poetics of the passage stress language while positing meaning and simultaneously withdrawing its finality. Nora

\footnotetext{
${ }^{8}$ Deconstruction questions the possibility of self-present truth and meaning. Signification, Derrida states, is necessarily the absence of this immediate meaning where differance creates a void, a space, or trace that allows for the infinite deferring and differencing of texts. That is, a cat is a cat because is not a hat or a bat or a rat. We only know cat because we associate it with a specific referent, not because the word or the sounds or the letters on the page have any kind of cat-ness to it.
} 
moves perpetually downward but stays in one place, attempting to stay fluidly centered. The "privacy of disappearance" allows for fluidity that Nora could not follow. She stayed "in one place" with the possibility of knowledge "perpetually before the eye" but not in it. Much like the monks later on keep knowledge "before their mind." The passage also alludes to the gaze of the other, as in "perpetually before the eye" or "I" and the necessity of the other in order to have meaning.

Nightwood presents a sophisticated and poetic description of time - its passing, its pauses, and its inevitable end. Djuna Barnes presents eight sections in Nightwood loosely tied together without much thematic or narrative coherence. The sections are not real chapters, per se, but more of necessary pauses possibly for the mere conventionality of a publishable novel. Andrew Field writes that, "Miss Barnes has all the time in the world and no time. There is a sense in everything she has ever written not so much of timelessness, but rather of time out of repair and heaped up as in an attic. The effect is produced by her language and the way it swans about between centuries" (34). In this timeless world, we find Nightwood's unlikely heroine, the girl that should have been a boy and the "eternal momentary": Robin Vote. Robin speaks only twice in the novel but her presence permeates the text. Robin seems to be everywhere acquiring thus an omnipresent kind of power without a beginning or end point. She marries Felix, she gives birth to Guido, only to have Nora and Jenny fall in love with her. Robin is first seen in the second section of the novel, "La Somnambule," where O'Connor and Felix find her on the floor of a common hotel room. Earlier in the chapter, Felix mentions that O'Connor's "favorite gesture" was plucking his nose hairs which seemed like a "vulgarization of what was once a thoughtful plucking of the beard" (31). Similarly, 
Robin is found in what seems like a vulgarization of a religious altar, alluding to the countless references to dogma, the clergy, and cathedrals in the novel:

On a bed, surrounded by a confusion of potted plants, exotic palms and cut flowers, faintly oversung by the notes of unseen birds, which seemed to have been forgotten, left without the usual silencing over (which, like cloaks on a funeral urns, are cast over their cages at night by good housewives), half flung off the support of the cushions from which, in a moment of threatened consciousness she had turned her head, lay the young woman, heavy and dishevelled. Her legs, in white flannel trousers, were spread as in a dace, the thick lacquered pumps looking too lively for the arrested step. Her hands, long and beautiful, lay on either side of her face (34).

Alluding to the many animalistic references in Nightwood, Robin is found unconscious, discovered as a new species is discovered by hunters in the outback. The scent in the room was reminiscent of church incense with the "oversung" hum of birds much like a church hymn on Sunday morning mass. Robin is "threatened" by consciousness as if sleep and the unconscious state were in fact her status quo. "Funeral urns" only add to the religious undertones of the scene while the mentioning of "good housewives" provides a solid feminist commentary. Robin is wearing white pants and nothing is mentioned of a top attire much like Jesus on the cross. Her hands were on each side of her face and her legs in a dancer's pose. She is "the troubling structure of a born somnambule, who lives in two worlds - meet of child and desperado" (34). Robin's androgyny in Nightwood is thus not one to be doubted or discarded. Her continual fluidity however, is what I argue is of utmost importance. A "somnambule" after all, exists only in motion - if it stops, much 
like the circus (as I discuss in subsequent pages) it stops being and becomes sleep. Robin must keep in motion as the androgyne must keep flowing in order to avoid being fixed in into a "third sex; much like the "somnambule" is unable to rest without necessarily losing what constitutes its being.

In this same scene, Felix experiences a "double confusion” seeing Matthew and Robin together - the two androgynes in one room. It is here that we learn Barnes' value of freedom and fluidity: "The woman who presents herself to the spectator as a 'picture' forever arranged, is for the contemplative mind the chiefest danger" (36). In other words, a woman who lives within "the grid" never questioning its finite, solid arrangement and always a picture of desirable femininity is the thinking person's worst enemy. Barnes goes on to describe her as "flesh that will become myth; as the unicorn is neither man nor beast deprived..." (36). Robin is not a coalescing of a man and woman but an androgyne lacking this duality. The mention of unicorns and myth seem to imply Robin is the materialization of the ineffable. Much like the unicorn exists outside of reality, so must Nightwood's heroine.

Examples of Robin's androgyny are vast in Nightwood, but it is the impetus for a centered fluidity and non-appropriation that anchors this analysis. Robin is "the converging halves of a broke fate, setting face, in sleep, toward itself in time, as an image and its reflection in a lake seem parted only by the hesitation in the hour" (37). Time and space do not seem to be real in the novel and Robin appears to walk liminally above or through it all without a solid image - she is the physical referent to the blur and continuous flux of the androgyne. Robin is the "converging halves" which presupposes motion and no specific end and presents the idea of synthetic or pseudo wholeness. That 
is, it portrays Robin still made up of "halves" - allegedly one male and one female - but lacking the sexual difference that the terms imply for they are converging, in movement and into the androgyne. The fate Barnes talks about could arguably be the social constructs of masculine and feminine and the belief that this duality predetermines who we are. Thus, Robin is the non-arrival of this converging thereby constituting the androgyne in terms of lacking sexual difference. By "setting face," Barnes gives us this physical referent and places Robin in the realm of the unconscious which may be symbolized by the lake water and of course sleep. Robin is attempting to signify as an imagine attempts to come through the reflection of water only to be disrupted by our perceived truth and reality. Moreover, a reflection could never fully signify since it is necessarily a copy of its original thus strengthening the argument against fully present meaning in my thesis. The "the hesitation in the hour" alludes to our inability to truly capture the androgyne's reflection perpetually and endlessly in time.

The tension remains, however: do we only know Robin and O'Connor as androgynous characters because they live liminally between both socially inscribed understanding of the sexes and outside of socio-normativity? Or does their always already existence predate any societal influences making them the ultimate center thereby essentializing them no matter how hard we try not to?

If signification is contextual and everything is relational then the androgyne defies naturalness by existing outside of this opposition and outside of binaric thinking. As a result, the androgyne attempts to blend in a prescribed world that refuses or is simply incapable of seeing its physical form. In Nightwood, Felix looks at Robin and finds "her presence painful, and yet a happiness. Thinking of her, visualizing her, was an extreme 
act of will; to recall her after she had gone, however, was as easy as the recollection of a sensation of beauty without its details" (45). If "all responsible witnessing engages a poetic experience of language" (Sovereignties in Question) then Felix had to be in an extra-discursive space to see and feel the sensation of Robin, and to witness the androgyne. Barnes' poetics need to be felt and experienced as a sensation, as an extradiscursive "sensation of a thought" much like Felix experienced Robin's presence. Paradoxically, it was in the church and through the eyes of a judging God that Robin's androgyny becomes arguably visible: “...as if some inscrutable wish for salvation, something monstrously unfulfilled had thrown a shadow...a tall girl with the body of a boy" (43). It is Robin's body that is deemed masculine, not her mind. Within dogmatic discourse, her desire for redemption is absurd and ridiculous because she is neither one of God's creations - a man nor a woman. Robin cannot be forgiven for her alleged sins ostensibly because she is not born from Adam or Eve or both. The monster, the deviant, the "other" has cast a shadow in the holy space of the devout Catholics simultaneously casting doubt on their own vows. She is "monstrously unfulfilled" as fully man, fully woman, or any coalescence of the two, but it is this lack of "fill" perceived by the devout that allows her shadow to be, albeit monstrously so. A shadow is thus a trace and a reflection. Much like the previous passage where the distortion was in the reflection of the lake water, this monstrous shadow again provides a referent allowing for Robin to be seen. How else do we perceive the androgyne if not as a deviant "other"?

Barnes considers the idea of divine salvation and human free will in Matthew O'Connor's telling of "Nikka the nigger who used to fight the bear in the Cirque de Paris" (14). Not only is this a reference to the carnivalesque and the transgressive, but 
also to race, slavery, denial of the flesh, androgyny and thus freedom and fluidity. O'Connor tells us that Nikka was covered in tattoos from head to toe and "Garlanded with rosebuds and hack-work of the devil, was he a sight to see!" (14). Nikka was in a cage, fighting a beast, and wearing roses around his neck while doing the devil's work. O'Connor describes Nikka's tattoos in detail including a "half public half private...quotation from the book of magic, a confirmation of Jansenist theory" and concludes with a regretful sentiment that he feels very sorry to have to bring this to their attention (15). At first glance, the ideas seem quite simple. Jansenism came about in the 1640s after the posthumous publication of Cornelius Jansen's Augustinus, and in its most basic form denied the necessity of God's grace to cleanse humanity of original sin by emphasizing free will and rejecting pre-destination. Jansenism rebelled against the primordial fall by maintaining that humanity was inherently good and denying this goodness caused great damage to all. This all carried an important message - the reconciliation of human choice with God's plan. In other words, a message of compromise indicated by the description Nikka's tattooed theory being half public and half private thanks to an "ill-concealed loin cloth" around Nikka's buttocks. However, Barnes does not specify what exactly the tattoo says but indicated that it comes from "the book of magic" possibly alluding to the impossibility of truth or the element of the "fantastic" in all religion. One can posit Nikka's rejection of humanity's inescapable goodness or damnation where no one is completely good nor bad ${ }^{9}$ nor anything in between. In a conversation with the Baron Felix Volkbein, Doctor Matthew O'Connor

\footnotetext{
${ }^{9}$ The notions of good or bad in this context, I theorize, can only be inferred from its most Biblical definitions. Goodness follows God's will and the bad work against it.
} 
explains that "Man was born damned and innocent from the start, and wretchedly - as he must - on those two themes - whistles his tune" (102). Always the performer and the charmer, O'Connor explains to the anguished Felix that humanity is neither good nor evil and we must, "wretchedly" so, navigate this space and "whistle our tune" while creating our own world - ostensibly allowing the androgyne to exists sans the duality of man and woman.

Another example of Jansenism and the free-will versus pre-destination in Nightwood is found in "Go Down, Matthew" when O'Connor asks, "Was Robin purposely unspun? Was Jenny a sitting bitch for fun? Who knows what knives harsh her apart?" (107). In other words, did Robin and Jenny follow their own path with full autonomy over their choices or were they part of a pre-assigned plan - be it a holy, religious plan or a societal world that attempts to dictate whom they must be. Jenny has her own chapter in Nightwood - "Squatter" - where we learn her home is full of secondhand things including a wedding ring she wears that previously belonged to someone else. This is relevant to my thesis insofar as it depicts Barnes' struggle to be outside of discourse but yet necessarily work within it. Moreover, when Nora asks the Doctor what he thought of Robin, he describes her as having a "...sort of fluid blue under her skin" (112) which I propose also connects Robin to Nikka's tattoos and Jansenism. As an androgyne, Robin is a deviant and just like Nikka, she is forced to battle the world in her "monstrous" state. Robin ostensibly wishes to exercise human free will while maintaining a relationship with the divine -ultimately the grounding, final signifier that is God. Barnes tells us that "[Robin] talked to the nuns and they, feeling that they were looking at someone who would never be able to ask for, or receive mercy, blessed her in their 
hearts..." (43). Robin is beyond salvation because again, the androgyne's always already ${ }^{10}$ quality puts it above and beyond God's will; much like the "fluid blue" flowing through her echoes back not only to the tattoo ink coalescing with her blood, but also to her royalty and sovereign "blue blood" status. That is, a "higher" kind of being impervious to rules others must follow.

“In Laughing at Leviticus: 'Nightwood' as Woman's Circus Epic”, Jane Marcus discusses the taboo of tattooing in Nightwood: "A tattoo, then, is not only taboo but is also a birthmark of the born-again — the self-created person who denies his/her birthidentity. This "monster" is a carnivalesque figure who revels in the taboo-shattering act of making the body a book, dissolving the difference between spirit and matter" (146). She explains that writing on the body is a denial of the "symbolic order" of things where Judeo Christian tradition is understood by way of the Holy Scriptures which presumes a complete separation of body and spirit (146). Coalescing holy text (spirit) and the flesh (body) again present Barnes' alleged desire for a centered fluidity. In other words, the blue ink running through Robin like blood must always move to avoid clotting. Blood is fluid but it centers in the heart. This may also be a commentary on the nature and culture duality that Nikka's tattooed body and the wild bear present fighting in a cage much like the gender and sex dilemma I have discussed. Nikka's body is a cultural and social commentary fighting against a raging bear that arguably represents nature and all the implicit, irrefutable constraints that my thesis argues against.

\footnotetext{
${ }^{10}$ The androgyne's always already quality means that it exists prior to the parts that define it. It is radically prior to man or woman.
} 
Jane Marcus believes Djuna Barnes was "fascinated with maquillage" (167). This is perhaps why Nightwood's characters are tattooed, cross-dressed, and thereby reject all "natural" claims to the body. Ostensibly then, they reject that genitalia dictates your experience as masculine or feminine although Nora, the one patriarchal subject in the novel, wants nothing but to control and appropriate Robin. Marcus points out "Nora's problem is the body/mind split" (167). Marcus understands that Nora sees herself as saving Robin and refuses to accept her physical need to be by Robin's side. Marcus goes on to state that,

[t]he great writer writes from the body. The dirty bed sheet is the writer's page. Patriarchal culture traditionally has seen woman as a blank page on which to write. So Nora sees Robin, and projects herself on to that page. Djuna Barnes's genius lies in her ability to overcome Nora's anxieties, and she is one of the few women writers whose novel was run off the same press as her bed sheets (167). This reference, which I analyze in detail in the following pages, alludes to the fifth chapter, "Watchman, What of the Night" where Nora walks into O'Connor's apartment and finds him fully dressed in drag sleeping in a bed with dirty sheets. Miss Barnes is not afraid to posit the body as a central theme in Nightwood. Marcus uses the dirty bed sheet image as a metaphor contrasted to that of the "blank page" which allows for a tradition of phallogocentric writing and manipulation. Barnes' great triumph, Marcus argues, is her ability to prevail over the pressure to conform to any standards and instead write the androgynous, sexually animalistic Robin while critiquing the "confines of the appropriate.” That is, the confines of the closed-circle androgyne made up of a sexual duality and the "appropriate" social constructs this duality entail. 
In Nightwood, Nora lives to be with Robin's body. She is a religious woman "without the joy and safety of the Catholic faith" (54). There is an impetus for physical closeness to the androgynous Robin. It is the "body of Robin" that causes Nora's tremendous ache, for it "could never be unloved, corrupt or put away" (51). Nora hunted the Parisian cafés for a sensation of Robin, knowing intrinsically that the androgyne could not be captured because that would imply its inevitable end. She looked "at every couple as they passed, into every carriage and car...trying to discover not Robin any longer, but traces of Robin, influences in her life, (and those which were yet to be betrayed)" (54). Nora understood that it was only in the "trace" that she could have Robin indicating like Felix did, that she could only see the androgyne within the poetics of language and the extra-discursive. Their years together were tumultuous and although Nora's masculinity attracted the fluid Robin, “...sometimes, going about the house, in passing each other, they would fall into an agonized embrace, looking into each other's face their two heads in their four hands, so strained together that the space that divided them seemed to be thrusting them apart" (52). Robin and Nora are depicted in movement while "passing each other" figuratively embracing themselves with their gaze, and almost monstrously with "two heads and four hands" as to portray the unnaturalness of their confinement. They were painfully "strained together" while the very space that should have allowed for their closeness did nothing but "thrust" them apart, much like two magnets are repelled by the very space that bonds their likeness. I speculate that in the following passage Robin plays along with Nora's overt violence and ostensible control because she understood that Nora would rather see her dead than promiscuous and free: 
...when I got [Robin] that far she began fighting so that suddenly, without thinking, but out of weariness and misery, I struck her; and at that she started, and smiled, and went up the stairs with me without complaint. She sat up in bed and ate eggs and called me, "Angel! Angel! and ate my eggs too, and turned over and went to sleep. Then I kissed her, holding her cold hands and feet and I said: 'Die now, so you will be quiet, so you will not be touched again by dirty hands; so you will not take my heart and my body and let them be nosed by dogs - die now, then you will be mine forever.' (What right has anyone to that?) (120).

Nora attempts to silence Robin and destroy the threat Robin's androgynous fluidity poses to Nora's patriarchy. It is Robin's repeated mention of “Angel!” and the overly eager eating of the eggs that leads me to read this as a cynical kind of bow down to masculinity. The parenthetical question is puzzling since it does not fit in with Nora's story. I believe this is Barnes' own rhetoric questioning her character's choices and the right of one side of a duality attempting to exert power over the other.

As I have shown, androgyny in a text is not just depicted in the context of gender and sexuality. The ideals of fluidity, movement, non-arrival, and the creation of a world versus the static representation depict the androgynous character as well. Nightwood, much like its title insinuates, analyzes deeply the idea of sleep, day, night and dawn. For instance, Miss Barnes does not paint a transparent picture of Paris in the 20s and 30s. Jeanette Winterson calls it a "seedy Paris of whores and cheap bars... the world that Robin Vote is drawn [to]" perhaps because she will not be judged in the secrecy of the night and a "stranger's embrace" (xi). Barnes uses the day and night metaphorically throughout the novel highlighting our necessity for one or the other, our destruction of 
one for the other, and most importantly, the option to not choose; to live liminally, and to take pleasure in the blurring of the binary:

I'm telling you of French nights at the moment," the doctor went on, "and why we all go into them. The night and the day are two travels, and the French-gutgreedy and fist-tight though they often are - alone leave testimony of the two in the dawn; we tear up the one for the sake of the other; not so the French. Any why is that; because they think of the two as one continually and keep it before their mind as the monks who repeat, 'Lord Jesus Christ, Son of God, have mercy upon me!' Some twelve thousand or more times a twenty-four hours, so that it is finally in the head, good or bad, without saying a word (89).

O’Connor separates night and day as two different "travels" just as the metaphysical separates man and woman; a duality fully rejected by Barnes and evident in O'Connor's and Robin's androgyny; after all, Robin was the invert, the boyish woman, the "eternal momentary" (135). Dawn is a rupture ${ }^{11}-$ it refuses to be a totality. Its trace is continuously coalescing into day from night with fluidity similar to the movement of the androgyne. O’Connor tells us we "travel" through night and day; moving, telling, signifying, and "leav[ing] testimony" in differance and thus in dawn. That is, dawn can allegedly be that space and that trace between signifier and signified that allows for that "sensation of a thought" that Barnes' speaks about to actually be. The absence of the totality of day and night allow the French to "alone leave testimony" in this space wherein the oppositional is impossible. How can we know day by knowing night? Or man by knowing woman, for that matter? Dawn creates a kind of aporetic space where

\footnotetext{
${ }^{11}$ In "Structure, Sign and Play in the Discourse of the Human Sciences" Derrida examines the notion that concepts who challenge accepted structures can be thought of as "events" or "ruptures."
} 
day is void of day-ness and night of night-ness. Neither is or was. Dawn is simply a trace. Miss Barnes brilliantly mentions how we discard one for the other and tells us the French "think of the two as one continually" - a phrase that can be analyzed in different ways: "continually" as it refers to the French thinking of day and night persistently, forever and always; or "continually" as it refers to day and night in continuous, forward movement; or both arguments at once never meant to be split or essentialized. In this ungrounding, the monks inevitably lean on God - the final signifier - while repeating "twelve thousand or more times" per day that the world they know seems to be rupturing without its ultimate meaning. In what was possibly just another absurdity by O'Connor, Barnes highlights the difficulty of our debt to the unthematized. After all, repeating anything twelve thousand times per day until it is "finally" intrinsic in us is a super-human effort. But what of the word "finally"? Is this a warning against turning this repetition into another final signifier? The monks, according to O'Connor, "keep it before their mind" arguably extra-discursively and outside of the rational metaphysical world - "it" being the blurring of binaries, the coming together of day and night, man and woman. Barnes explicitly mentions the monks keep this not only outside of their heads or rational thinking, but "before" it as in primordially or superiorly.

Because we very realistically need it to avoid human anxiety and anguish, teleological thinking highlights the importance of always moving toward something definitive. This kind of "operational thinking," David Wood asserts, is just as important as ungrounding our existence with the deconstructive process, “...has the distinct virtue of facilitating constructive complexity in a certain kind of human engagement with the world. Once we are assured of the viability of its key concepts in a particular region, it 
offers powerful tools for constructing and managing possible future scenarios" (3). Wood goes on to explain that a certain kind of anxiety in us is inevitable without our ability to work within the "grid" (2). These "grids" or "mappings" are always "prescriptive" and fully present before we have a chance to create any part of them. Operational thinking, therefore, is representational thinking forcing us to exist within the terms of an allegedly already meaningful world and its ultimate reality instead of participating and creating a world along with its signification. Wood's analyses is thus crucial to this paper insofar as it explains our necessity to live in this representation world and language while understanding that this socially constructed "reality" is in fact not intrinsic nor natural in any way. We must acknowledge both, that an extra-discursive possibility exists and that we are linguistically constituted. That is, a possibility outside of discourse and our grasp of language exists that can only be expressed as an event, a movement, an explosion, or a rupture - ergo the infinite the androgyne's "synthetic wholeness" lacking sexual difference and not constituted of male or female.

I consider the autobiographical aspect of Djuna Barnes and Nightwood just as important the actual text of the novel. Barnes wrote Nightwood amidst a terrible and painful ambiguity about her relationship with Thelma Woods. In a letter to her dear friend Emily Coleman dated September $20^{\text {th }}, 1935$, Barnes reminds Coleman that at the time Barnes did not know whether Thelma would come back into her life. She indicated a certain anxiety over having to read the story to Thelma and thus over the telling: "([I] knew that as I wr[o]te it I should have to read it so to her) whether I could live with her again or not..." (qtd. in Cheryl Plumb's introduction ix). "Meaning", etymologically speaking, is "to tell," "to say," or "to desire"; therefore, before or as something has 
meaning there is an imperative of difference and an awareness of the "other" which inevitably presupposes space and trace. That is to say, "to mean... is automatically not to be. As soon as there is meaning, there is difference" (Dissemination ix). It is arguable, thus, that for Barnes the meaning of Nightwood was ultimately founded on the act of telling the story and in particular of telling it to Thelma. If being as be-ing in differance is continual and does not posit signification definitively, it is precisely that which makes signification possible in the first place. If meaning to Barnes came from or is integrally related to the telling, then Nightwood means in a particular way as a narrative for and to Thelma. In this space of ontological differance, it is the telling that means and not the told (i.e., the signified); it is the saying and not the said that "insinuates" - to use Barnes' Nightwood rhetoric - meaning and signification.

In Nightwood, characters flow in and out of societal woman-ness or man-ness in what Suzette Henke calls it a "deconstructive critic's nightmare." She states that "[i]t is a text modeled on infinite semiosis, on a wilderness of sliding signifiers that refuse to be pinned down and rattle with echoes of undefined meaning, shadows of psychic states indefinitely deferred" (331). I agree with much of Henke's criticism on Nightwood, but it is precisely the "wilderness of sliding signifiers" that makes this text fully deconstructable and androgynous for that matter. "Pinning" down signifiers would seem to essentialize them which is exactly what deconstruction aims to avoid. It is in the "echoes of undefined meaning" and in the space these echoes navigate that we find differance and a unique and non-representational possible signification. Consequently, how is gender defined in this non-economy? Kari Weil and Toril Moi briefly touch on a few theories on the subject including Irigaray's idea of stabilizing two different separate 
genders without a patriarchal center. Moi criticizes Irigaray for ultimately defining 'woman' and thus “essentializing her' (Sexual/Textual Politics 139) and also Cixous for lacking any kind of pragmatic utility in her feminine utopia theories: "It is just this absence of any specific analysis of the material factors preventing women from writing that constitutes a major weakness in Cioux's utopia" (Sexual/Textual Politics 121). There is no lack of feminist, philosophical, and post-modern theories analyzing gender, femininity, androgyny, and patriarchy. One theory debunks the next and every single one asserts a new, comprehensive way to understand the subject. Although I am not certain androgynous critique can be completely outside of the feminist realm, Carolyn Heilbrun makes a strong distinction between the two but asserts that "the confusion is almost inevitable" (58). Because of social sexual polarization where women's identity comes from their relationship with male figures, it is obvious to see the androgynous and feminine ideals as one and the same. At the risk of sounding reductive, I think it is important to note that in the androgynous novel, "the reader identifies with the male and female characters equally; in feminist novels, only with the female hero" (58). This is a non-confining generality, but one that I consider significant in order to pose a slight distinction between schools of thought.

Apart from feminist and androgynous, Nightwood is also a carnivalesque piece. Frau Mann, also known by her stage name, "Duchess of Broadback," is the trapeze artist whose performing attire seems like a second skin to her muscular structure: “...one somehow felt [her clothes] ran through her as the design runs through hard holiday candies, and the bulge in the groin where she took the bar... The stuff of the tights was no longer a covering, it was herself; the span of the tightly stitched crotch was so much 
her own flesh that she was as unsexed as a doll" (12). Frau Mann became her attire and was one with her trade. Her performing outfit was no longer "a covering" - it was all she was. The clothes running through her are indicative of the blue ink running through Nikka's skin. Much like Nikka was one with the text of his tattoo, so was Frau Mann with the text of her attire. Barnes mentions that the design blended around her like holiday candy - alternating colors without a beginning or end but converging at the end much like Robin was the "converging halves of a broken fate." The alternating colors, like her ostentatious feminine attire and her masculine body, blended into one as she performed her circus act. Both, Frau Mann's actual name and stage name comprise feminine and masculine connotations - "Mann" and "Broadback" alluding to her strength and masculinity. In addition, "Frau" in German means "woman" and it is also a term used to address married or widowed women. "Mann" in German means "man." This makes Frau Mann "Woman Mann" or "Mrs. Mann" - another articulation of her androgyny.

Women who are "pre-arranged" and follow the ground stay within Wood's "grid" and "mappings" and thus stand to lose the possibilities of extra-discursivity and the freedom of movement. In this context, they follow the prescribed gender designation. The freedom of the air allows for Frau Mann's androgyny and gender to flow freely without boundaries or constraints. Ideally, her motion would be endless, epitomizing the centered fluidity I speak about throughout this paper.

The circus in Nightwood seems to reinforce the sense of displacement and ambiguity of the story, and serves as a sort of microcosm welcoming everything and everyone outside of the accepted normative and cultural lines. Outlandish make-up, brightly color wigs, androgynous artists, and a blurring of man and beast attract 
spectators who pay a fee to witness their act, their novelty, and ultimately their life.

Barnes tell us that " $[\mathrm{t}] \mathrm{he}$ emotional spiral of the circus, taking its flight from the immense disqualification of the public, rebounding from its illimitable hope, produced in Felix longing and disquiet. The circus was a loved thing he could never touch, therefore never know." The spectacle of the circus - allegedly an allegory for society in the 1930s "took its flight," soared, and succeeded because of its incongruence with the metaphysical world. That is, its "immense disqualification of the public" and from the representational allowed the circus its perpetual movement without needing to conform to what is being prescribed. What allowed the circus to be was the "rebounding," ostensibly its trace and differance from "illimitable hope" insofar as it never posited absolute is-ness because it never was. How can the circus, like the somnambule truly be (in terms of fully present meaning and being) if its most basic quality is lack of full presence? The circus, by its most basic function in the world is never steady, traveling from city to city, always in flux with changing colors, artists, and acts. It is, in fact, the perfect deconstructive scenario. If it ever stopped moving, it would stop being. Felix needed to touch and physically feel something to know it and ostensibly own it. He could never truly know the circus and ultimately know his wife in the phallogocentric manner to which he was accustomed, because neither were able to stop their fluid movement.

Felix "insinuates" his way "into the pageantry of the circus and the theatre. In some way they linked his emotions to the higher and unattainable pageantry of kings and queens" (13). For Felix, the circus was an untouchable, unattainable world inhabited by people whose desires were "utterly divergent from his own" (14). The mere idea of insinuation, I believe, fits well with the deconstructive and androgynous events insofar as 
it too must be practiced as an event. When we insinuate something, we put it forward and simultaneously withdraw never positing final, absolute meaning.

It is interesting to note that the circus was "inhabited by people" and not the other way around as in "people inhabited the circus." The prior seems to imply that within its other-ness, the circus still prescribed a set of rules for its inhabitants. Felix ultimately insinuated himself into Christianity, into the "Baron" societal status, and into Robin Vote's life. Nevertheless, Felix understood quickly that he would never be able to mold Robin into a wife, mother, and Baronin: "He knew that he was not sufficient to make her what he had hoped; it would require more than his own argument. It would require contact with persons exonerated of their earthly condition...” (42).

People who are "exonerated from their earthly condition" could arguably be found in the circus, its transgressiveness, and ungrounding of reality. Felix identified with made up titles like "Princess Nadja" or "Baron von Tink" since his identity rested upon a phony Baron label and a life-size portrait of a strange Christian family he never knew. Barnes tells us that "Felix clung to his title to dazzle his own estrangement" and that it was this rupture, this separation, this rift that brought Felix and the circus together. The use of "dazzle" in this sentence is twofold - appealing to circus, the light, the glitter, and the spectacle; and highlighting the inescapable web of lies he constructed and attempted to pass on to Robin through their marriage.

Felix understood that although Robin bore his child, she was not his to keep. Robin "had greatness hidden in the non-committal. He felt that her attention, somehow in spite of him, had already been taken, by something not yet in history. Always she seemed to be listening to the echo of some foray in the blood, that had no known setting; and 
when he came to know her this was all he could base his intimacy upon" (42). Robin was uncommitted to sex, gender, motherhood, and the restrictions these inherently imply. Her attention was already taken, ostensibly by something extra-discursive or "not yet in history." There was an apparent "foray" or attack within Robin's blood - possibly the only way that Felix could begin to comprehend and feel the sensation of Robin's androgyny. After all, Felix was very concerned with blood, ancestry, and history. Barnes describes Felix as "pathetic...with [a] tightly held monocle...wrecking himself and his peace of mind in an effort to acquaint [Robin] with the destiny for which he had chosen her..." (42). However, Robin took to wandering after bearing Felix's child and rejected the limitations her husband attempted to impose on her. "She came back hours, days later, disinterested. People were uneasy when she spoke to them, confronted with a catastrophe that had yet no beginning" (45). The androgynous Robin kept in motion and her presence was hard to decipher - she could only be perceived as perpetual chaos without beginning nor end. When giving birth to her son, Barnes tells us that "Amid loud and frantic cries of affirmation and despair, Robin was delivered" - alluding to the possibility of divine forgiveness of her sins in exchange for the creation of life. However, "her prayer was monstrous, because in it there was no margin left for damnation or forgiveness, for praise or for blame - those who cannot conceive a bargain cannot be saved or damned" (43). She functioned outside of an economy of exchange. Robin is caught in the middle, in an extra-discursive existence outside of God's touch and thus unable to bargain for divine grace. The fluid androgyne is neither saved nor damned nor male nor female nor a combination of either. There is nothing to forgive or damn her for 
- she simply exists and functions under a non-metaphysical God existing outside of the realm of bargaining.

Examples of androgyny and in particular the denial of femininity and motherhood pervade the novel. In fact, Nightwood begins with the transgressive ${ }^{12}$ image of Hedvig Volkbein, a woman of "military beauty," giving birth to Felix and immediately "thrust[ing the baby] from her" (3), which can be read as in some way related to George Bataille's notion that we are all discontinuous beings - we are born alone and we die alone. Hedvig was forty-five and well passed the optimal age for childbearing. She immediately dies after rejecting her newborn while lying on a red bed spread with a "valance stamped with the bifurcated wings of the House of Hapsburg" (3). Since we have established that boundaries and limits are not something Djuna Barnes wishes to abide by - the sheer "unnaturalness" of a mother thrusting a newborn away highlights this very principle. The picture on the valance is bifurcated, split in two, incomplete and thus not whole - possibly alluding to the alleged male and female duality. Hedvig is said to be strong and her beauty "military" and names her child "with the gross splendor of a general saluting the flag" (3). In other words, even during the ultimate feminine act of giving birth, Hedvig exhibits great masculinity allowing for the androgynous tone of the

\footnotetext{
${ }^{12}$ While examining transgressive theorists, it is interesting to note Nightwood's connection to George Bataille's introduction to Death and Sensuality. In his work, Bataille details the inevitable bond between eroticism and death and believes that humans are discontinuous but cannot accept being so. We are always in search of continuity and wholeness and he describes the violent division of mother and child upon birth as an example of our incompleteness. Bataille explains that this is when we recognize the "gulf" that stands between us and the other and that eroticism is our response to this separation and the anxiety that comes from it. We cannot be erotic without the other or the idea of an other. Bataille deduces and concludes that reproduction and death are the primary elements constituting eroticism while further explaining that death equals continuity and reproduction is continuity and the death of continuity. The opening scene of Nightwood is a solid example of Bataille's ideals. The mother, Hedvig, dies after reproduction only to continue on to death while leaving a piece of her behind embodied as Felix.
} 
novel to be perceived from the start and from Felix's conception. Lastly, is the mention of the House of Hapsburg ${ }^{13}$, a royal family from Austria which became extinct in $18^{\text {th }}$ century as a result of inbreeding ${ }^{14}$. This entire scene takes place on a red bedspread intensifying the image of blood, life, and its inevitable flow.

In Transgression, Chris Jenks explains that "[t]o transgress is to go beyond the bounds or limits set by a commandment or law or convention, it is to violate or infringe. But to transgress is also more than this, it is to announce and even laudate the commandment, the law or the convention. Transgression is a deeply reflexive act of denial and affirmation" (Jenks 2). Consequently, the mere act of transgression implies a challenging of established laws or conventions and the breaking of rules while simultaneously stressing the existence of that which is being rejected in the first place. This dynamic mirrors the androgyne to the extent that the more we attempt to stress the importance of its movement and constitution outside of either sex or gender, the more we reinforce the same principle we are attempting to avoid. That is to say, there is an inevitable movement or presence and absence, of presentation and withdrawal and ultimately differance.

Djuna Barnes seamlessly joins George Bataille's transgressive discourse of violence and ontological fragmentation (i.e., discontinuous being) by placing a copy of

\footnotetext{
${ }^{13}$ Also spelled Habsburg

${ }^{14}$ According to the Habsburg Family Association, http://habsburg.yolasite.com
} 
the memoirs ${ }^{15}$ of the Marquis de $\operatorname{Sade}^{16}$ in the hands of Robin Vote while her husband watches her sleep:

When Felix returned that evening Robin was dozing in a chair, one hand under her cheek and one arm fallen. A book was lying on the floor beneath her hand. The book was the memoirs of the Marquis de Sade; a line was underscored: Et lui rendit pendant sa captivité les milles services qu'un amour dévoué est seul capable de rendre ${ }^{17}$, and suddenly into his mind came the question: "What is wrong?" (51).

Robin was "dozing" and not sleeping - a word that seems to imply a kind of liminal, superficial rest. One who dozes is not deeply asleep, nor sharply awake, but in a suspended state much like dawn is neither day nor night. Shouldn't Robin be watching after her child instead? One of her hands is under her face and the other has "fallen" much like her fall from her expected womanly grace. The sheer violence emitting from the memoirs of de Sade is enough to set the tone for this scene but the fact that she had written on it and underscored a line is even more compelling. Robin has engaged with de Sade's prose and has underscored a section speaking of captivity, distance, and love. In

\footnotetext{
${ }^{15}$ Cheryl Plumb points out that there is no record of de Sade ever writing memoirs and calls this reference "puzzling" (220).

${ }^{16}$ According to Berbegal, transgression is not rebellion. The idea has been analyzed for centuries most notably by Bataille who is usually placed at the center of transgressive ideals and who emulates much of the Marquis de Sade's writings. Bataille's writings are about politics and social standards but his ideas are convoluted and shocking to the average reader. For instance, Chris Jenks explains that Bataille writes about excrement not because he wants to just speak about the thing itself, but "because it is rude" and because "he is also talking about the body of collective social life and those excreted, excluded, expunged, like the bad, the insane, the deviant, the poor, the marginal, the dispossessed" (89). Jenks explains that transgression allows us to do this without having to abide by the social standards of politeness.

${ }^{17}$ Cheryl Plum translates this as: "And he rendered to his captivity the thousand services that devoted love is alone capable of rendering." She points out that Barnes probably meant "captive" and not "captivity" (220).
} 
her "dozing," Robin has related to feeling trapped in a life that is not hers, to which Felix wonders "what is wrong?" - a very powerful thought in this context for it could have various meanings. What is wrong with him and his own inability to live his real identity? What is wrong with Robin who seems incapable of being a "normal" spouse and mother? What is wrong with this being wrong? And what right is this wrong being compared against? The ultimate irony being that he is questioning all of it seeking to circumscribe instead of just letting it all be which is inevitable diffuse and indefinable. If through transgression we explore a Godless world without limits allowing for the androgyne's movement and existence, these questions have no end as per Foucault's belief on the infinity of interpretations. Foucault also believed in the intrinsic violence of these interpretations since meanings are inevitably distorted no matter how hard we try to attain some kind of ultimate truth (Bebergal).

Transgression, outcasts, inverts, and social deviance pervade Nightwood. It is a story of displacements, categories and the boundaries these inevitably impose. I argue that Barnes attempts to move outside the confines of boundaries and categories by writing a novel whose prose and themes support the fluidity of the androgyne. Much like Barnes denied being a lesbian, characters in Nightwood deny being suppressed by boundaries and categories. Robin Vote and Hedvig Volkbein deny motherhood, Guido and Felix deny Jewish-ness, Jenny is "the subject of removal" and squatter defined by the negative, that is by absence rather than presence. Nora denies womanhood by attempting a patriarchal control over Robin, and Matthew O'Connor wishes, more than anything to be a woman. Matthew's androgyny is different from the Robin's. He feels trapped as “the bearded lady" and critics call him Barnes' parody of the sham sexual expert and 
patriarchal authority. In other words, "Matthew speaks with the authority of his masculine subjectivity and his status as a doctor. But these traditional bases of authority are blatantly undercut by the fact that he is a would-be woman and an unlicensed quack" (Harris 63). Matthew speaks with the conviction of an omnipresent power, but we eventually realize that this is Barnes' satire for anyone who attempts to know and define a woman. The doctor, in his ultimate desire to vacillate between man and woman, studies women's bodies and dresses up as one. In Other Sexes: Rewriting Difference From Woolf to Winterson, Andrea Harris observes that "while on the one hand Matthew is sophisticated in his reading of gender ambiguity, particularly its manifestations in inversion, on the other hand he uses the feminine masquerade as a means of arriving" (64) ostensibly to womanhood. Matthew is both, a personification of the male/female duality and a questioner of its value and existence.

In the following passage, O'Connor questions our necessity for gender demarcation:

What is love we have for the invert, boy or girl? It was they who were spoken of in every romance that we ever read. The girl lost, what is she but the Prince found? The Prince on the white horse that we have always been seeking. And the pretty lad who is a girl, what but the prince-princess in point lace - neither one and half the other, the painting on the fan! We love them for that reason. We were impaled in our childhood upon them as they rode through our primers, the sweetest lie of all, now come to be in boy or girl, for in the girl it is the prince, and in the boy it is the girl that makes a prince a prince - not a man. ... They are 
our answer to what our grandmothers were told love was, and that it never came to be; they, the living lie of our centuries (114).

O'Connor supports the fluidity of gender by asserting that the girl lost and the prince found are "neither one and half the other," inevitably moving as if they were hanging from a fan. The entire book reads as a paining hanging from a fan where every color and every character is blended and blurred into the next while seamlessly flowing within. It is interesting to note that although O'Connor emphasizes the multiplicity and non-confining state of gender and thus androgyny, he anchors his idea of the "invert" in an unimpeachable gender duality (Harris 64). That is, you can only be an invert based on a static opposite. However, he does qualify his statement of the "invert" in this passage by affirming that Robin was the invert "boy or girl." In other words, Robin is an invert of both sexes. She is the boy that should have been a girl and the girl that should have been a boy.

If in the boy is the girl that makes the prince, a prince - not a man, then it is the mythological girl-ness that makes him ethereal, royalty, an imaginary prince existing only outside of discourse much like the unicorn comes from "flesh that will become myth." This entire passage embodies the so called "truth" of love, sex, and gender passed on by our grandmothers and thus socially constructed. It is the "sweetest lie" "impaled" in us although O'Connor understands this "never came to be."

Apart from serving as the charlatan and comic relief in the story, Matthew "Mighty" O'Connor seems to connect each character to each other. Nevertheless, we must take everything Matthew-Might-grain-of-salt-Dante-O’Connor says with a fine grain of salt. He is a self-proclaimed doctor and outlandish charlatan. Yet, much like a 
court jester, O'Connor's rhetoric is only superficially comical as the "divine idiot and a wise man" (Nightwood 32) of the story. Susana Martins claims that "O'Connor expresses notions of identity as determined by the body, and his insistence on the body as root identity suggests that the psyche...is not the sole field of meaning for individual experience and identity" (111). The androgyne still needs a body to live in and we must physically work within Wood's "grid" while asserting the existence of the extradiscursive. Ultimately, O'Connor's rhetoric leads us to understand that language - much like Foucault's insistence on the violence of all interpretation - is ultimately complex and multiple: "Yes, we who are full of the gorge with misery, should look well around, doubting everything seen, done, spoken, precisely because we have a word for it, and not its alchemy" (Barnes 72). Language, if understood metaphysically, crystallizes and inhibits truth which is actually fluid and alchemic. We cannot separate our existence from language and the world and thus can only take responsibility for what we understand from any given conceptual grounding. Language rejects and incites appropriation all at once. It simply cannot not (Derrida 101) due to differance - the dynamic by which signification or meaning happens as an event. Thus, Martins explains that "What O'Connor wants is not a female body, but the signifiers of femaleness that re-present an alleged reality. His exaggerated metaphors suggest that his apparent acceptance of traditional gender categories is actually an acknowledgment of their discursive origins" (113). That is to say, O'Connor's personification of a woman in drag insinuates not a desire to physically be one, but to know the meanings or signifiers of woman-ness ${ }^{18}$. He seems to accept gender but a closer reading of his language denotes an understanding that

\footnotetext{
${ }^{18}$ Ultimately the signifiers constitute the meaning
} 
maleness and femaleness are in fact social constructs, that is to say they have "discursive origins."

In this reading, Matthew O'Connor's outlandish cross-dressing can be read as a kind of melancholic nostalgia for womanhood. Nostalgia for definitive gender categories allows his femininity to exist by positing and withdrawing the idea within a "sensation" and not a physical event. That is to say, he understands nostalgia as an event outside of discursivity that is felt but not acknowledged as such. For instance, when speaking to Felix, O'Connor mentions "raising his large melancholy eyes with the bright twinkle that often came into them: "Why is it that whenever I hear music I think I'm a bride?"” (33). In other words, he understands the sensation of femininity but cannot or will not translate it into being a bride, for instance. O'Connor is thus haunted by the sensation of womanhood. Consequently, when Nora visits his home in utter distress over the loss of Robin, she finds the Doctor "In the narrow iron bed, with its heavy and dirty linen sheets...in a woman's flannel night gown. The doctor's head...was framed in the golden semi-circle of a wig with long pendent curls that touched his shoulders.... He was heavily rouged and his lashes painted" (Nightwood 69). After asking him to tell her all he knew about the night, Nora wonders "why she was so dismayed to have come upon the doctor at the hour when he had evacuated custom and gone back into his dress" (Nightwood 69). In other words, Nora would have rather to see him play the perfunctory role of male doctor and orator, rather than seeing him in "his dress" which much like Frau Mann, has the effect of becoming yourself. Nora, after all, believes in the "word" and anything outside of the "norm" must bother her. 
Becoming his female patients, allow Matthew O'Connor to “examine the gender binary and to construe more complex models of fluid gender identifications on the wideranging gender spectrum" (Harris 64). That is why O'Connor understands the reductive quality of language, the necessity of acknowledging extra-discursivity, and thus the fluid, "alchemy" of gender. "There is no truth, and you have set it between you..."Matthew tells Nora. "[Y]ou have been unwise enough to make a formula; you have dressed the unknowable in the garments of the known" (114). Matthew asserts the impossibility of true and absolute meaning and warns Nora that she has "set" this between her and Robin. In other words, Nora has concocted a "truth" about Robin in an attempt to crystallize Robin which has done nothing but push her away from Nora. The "formula" is ostensibly the said crystallization of the unknown and unpinnable alchemy of Robin. Ultimately, Nora has attempted to put a known "dress" on the fluid, body of the unknown androgyne. There is a continuous mention of dresses and clothing in the novel alluding to the superficiality and classification of "male" and "female" outfits as well as the previous mentions of garments and gowns becoming their wearers as with Frau Mann and Matthew O'Connor.

I find it interesting that critics seldom discuss Djuna Barnes' mention of Salome in the Nightwood. Matthew tells Felix in the novel that he is no "herbalist" nor "mountebank... ...neither friar nor yet a thirteenth-century Salome dancing arse up on a pair of Toledo blades - try to get any love-sick girl, male or female, to do that to-day!” (17). Salome was a Victorian play by Oscar Wilde which has been notably known as androgynous not only by the aggressiveness and malevolence of its title character, but also by the drawings and art that accompanied its publication. The pictures seemed to 
lack sex, gender and thus difference making it almost impossible to differentiate Salome from the male figures around her. In Nightwood, this is another significant level of the androgynous reading of the novel. Likewise, Matthew's questioning of the of the "lovesick girl's" sex and gender as "male or female" underscores my previous analyses of the doctor as an examiner of this duality and questioner of "natural" truth.

Nightwood's plot is indefinably secondary to its prose. Its form and context overlap and are mutually constitutive: "Once out in the open Robin walked in a formless meditation. ... She walked with raised head, seeming to look every passer-by, yet her gaze was anchored in anticipation and regret" (65). In this description, Barnes never asserts that anyone else sees Robin - after all, she was "formless," endless and unbounded. Although the idea of "forms" is Platonic and possibly essentializing, Barnes uses it to describe "meditation" which can exist outside of the representational. Moreover, walking in a "formless meditation" also references Robin as a somnambule or sleep walker. She is the androgyne in motion existing liminally between sleep and awake. It is Robin that seems to look at everyone but no one quite sees the androgynous, "wandering Robin" (52) with the "body of a boy" (50). “...[Y]et her gaze was anchored in anticipation" - not a ground but a looking forward and back thematizing the horizons of continuity and the perpetual positing and withdrawing of meaning. "Gaze" is a nonarriving event and "anchored" is the opposite and almost implies a forceful fixidity. Things are only oxymoronically anchored. In addition, "anticipation" is an insinuation, a desire, a being thrown forward; and "regret" withdraws that immediate anticipation again with a forceful quality to it. Both deny temporal coincidence and both highlight nonpresence and non-identity - looking forward and looking back. Barnes poetically posits, 
withdraws, then posits and withdraws again. Nightwood, thus, expresses the great freedom and agency in the extra-discursive and deconstruction. The numerous narratives in the text highlight the marginalized and exiled - the homosexuals, the Jews, the androgynous, the ex-patriots. "The achievement then," David Wood asserts, "is not a terminus ad quem, not a point in time, but a different way of relating to time. We should embrace the ambiguity, the contingency and the ungroundedness - the recognition of ongoing contingent engaged temporality as the plane on which we all must make our fragile sense" (7).

It is the impossibility of natural truth or fully present meaning that Jaques Derrida questions in "Language is Never Owned." Derrida asserts that "It is the essence of language that language does not let itself be appropriated. Language is precisely what does not let itself be possessed but, for this very reason, provokes all kinds of movements of appropriation" (Sovergnities 101). Nightwood's rhetoric very much illustrates this principle not only it is overall theme and rhetoric, but in paradoxically concrete detail with the elusive lives of Robin Vote and Matthew O'Connor's, and their intrinsic understanding of the impossibility of meaning. Simultaneously, they attempt to physically be women thereby reinscribing the male/female binary and its meaning. Much like the hermaphrodite haunts the androgyne, I feel language haunts intrinsic signification and meaning.

Jeanette Winterson calls the novel "demanding" and warns that you "can slide into it, because the prose has a narcotic quality, but you can't slide over it. The language is not about conveying information; it is about conveying meaning" (Introduction to Nightwood $\mathrm{x}$ ). Chapters in the novel are juxtaposed without much sense of classical 
sequence and the plot is ambiguous at best. The explicit use of the androgynous figure is supported by the poetic nature of the text which according to Derrida, never presupposes a meaning while intrinsically acknowledging that a final being is impossible (Poetics of Witnessing). Much like Robin never arrives home and Felix never touches the circus, Djuna Barnes' Nightwood never arrives to a classical and satisfactory "fulfilling" ending. “Have you ever loved someone and it became yourself?" Nora asks O'Connor (161), ostensibly understanding that love pushes against all boundaries of precision and containment, and that becoming "it" implies being/becoming free and limitless. "Robin can go anywhere, do anything" Nora continued, "because she forgets, and I nowhere because I remember" (161). By forgetting, Robin flies and creates; by remembering, Nora stays grounded and well within the representational never quite understanding that "One's life is peculiarly one's own when one has invented it" (Nightwood 125). If Barnes' does anything in Nightwood, is to present a prescriptive world of androgynous understandings detached from the proper, while negotiating our physical existence in world of blurring boundaries successfully moving toward the horizons of continuity. 


\section{LIST OF REFERENCES}

Barnes, Djuna. Nightwood. 1937. New York, NY: New Directions Publishing Corporation, 2006. Print.

Barnes, Djuna. Nightwood: The Original Version and Related Drafts. Ed. Cheryl J. Plumb. New York: Dalkey Archive Press, 1995. Print.

Bataille, Georges. Eroticism: Death and Sensuality. San Francisco: City Lights, 1986. Print.

Bebergal, Peter. "A Meditation on Transgression Foucault, Bataille and the Retrieval of the Limit ." ctheory.net. Ed. Arthur Kroker and Marilouise Kroker. N.p., 6 May 1998. Web. 7 March 2012.

Derrida, Jacques. Dissemination. New York, NY: Continuum, 1891. Print.

---. Sovereignties in Question: The Poetics of Paul Celan. New York: Fordham University Press, 2005. Print.

Chanter, Tina. Gender: Key Concepts in Philosophy. Cornwall, UK: MPG Books Ltd, 2006. Print.

Eliot, T.S. The Waste Land and Other Poems. Ed. Frank Kermode. New York, NY: Penguin Books, 2003. Print.

Field, Andrew. Djuna: The Life and Times of Djuna Barnes. New York, NY: G. P. Putman's Sons, 1983. Print.

Foucault, Michael. History of Sexuality, Volume I: An Introduction. Trans. Robert Hurley. New York, NY: Random House, Inc., 1978. Print.

Foucault, Michel, Donald F. Bouchard, and Sherry Simon. "A Preface to Transgression." Language, Counter-memory, Practice: Selected Essays and Interviews. Ithaca, NY: Cornell UP, 1977. 29-52. Print.

Harris, Andrea L. Other Sexes: Rewriting Difference From Woolf to Winterson. New York: State University of New York Press, 2000. Print.

Heilbrun, Carolyn G. Toward a Recognition of Androgyny. New York and London: W.W. Norton \& Company, 1964. Print.

Jagger, Gill. Judith Butler: Sexual Politics, Social Change and the Power of the Performative. New York, NY: Routledge, 2008. Print. 
Jenks, Chris. Transgression. New York, NY: Routledge, 2003. Print.

Joyce, James. Ulysses. New York: Random House, Inc., 2002. Print.

Marcus, Jane. 'Laughing at Leviticus: 'Nightwood' as Woman's Circus Epic." Cultural Critique: The Construction of Gender and Modes of Social Division 13 (1989): 143190. JSTOR. Web. 8 June 2012.

Martins, Susana S. "Gender Trouble and Lesbian Desire in Djuna Barnes's 'Nightwood."' Frontiers: A Journal of Women Studies 20.3 (1999): 108-126. JSTOR. Web. 4 December 2011.

Moi, Toril. Sexual/Textual Politics. 1985. New York, NY: Routledge, 2002. Print.

Ovid. Metamorphose. Trans. Rolfe Humphries. Bloomington, IN: Indiana University Press, 1983. Print.

Rado, Lisa. The Modern Androgyne Imagination: A Failed Sublime. Charlottesville and London: University Press of Virginia, 2000. Print.

Showalter, Elaine. A Literature of Their Own. New Jersey: Princeton University Press, 1977. Print.

Weil, Kari. Androgyny and the Denial of Difference. Charlottesville and London: University Press of Virginia, 1992. Print.

Wood, David C. The Step Back: Ethics and Politics After Deconstruction. Albany, NY: The State University of New York Press, 2005. Print.

Woolf, Virginia. A Room of One's Own. 1929. New York and London: Harcourt, Brace, Jovanovich, 1957. Print.

---. Orlando. 1928. New York, NY: Harcourt Books, Inc., 2006. Print. 


\section{BIBLIOGRAPHY}

Archer, Margaret S. Being Human: The Problem of Agency. Cambridge, UK: Cambridge University Press, 2000. Print.

Armour, Ellen T. Deconstruction, Feminist Theology, and the Problem of Difference: Subverting the Race/Gender Divide. Chicago, IL: The University of Chicago Press, 1999. Print.

Bazin, Nancy Topin. Virginia Woolf and the Androgynous Vision. New Brunswick, NJ: Rutgers State University Press, 1973. Print.

Brisson, Luc. Sexual Ambivalence: Androgyny and Hermaphroditism in Graeco-Roman Antiquity. Berkeley, California: University of California Press, 2002. Print.

Burns, Christy. "Re-Dressing Feminist Identities: Tensions between Essential and Constructed Selves in Virginia Woolf's Orlando." Twentieth Century Literature 40.3 (1994): 324-364. JSTOR. Web. 5 August 2011.

Cixous, Hélène. "Laugh of the Medusa." Trans. Keith Cohen and Paula Cohen. Signs 1.4 (1976): 875-893. JSTOR. Web. 1 January 2011.

Dettmar, Kevin J.H., Ed. Rereading the New: A Backward Glance at Modernism. Michigan: The University of Michigan Press, 1992. Print.

Earnshaw, Steven. Existentialism: A Guide for the Perplexed. Trowbridge, UK: Cromwell Press Ltd, 2006. Print.

Hargreaves, Tracy. Androgyny in Modern Literature. New York, NY: Palgrave MacMillan, 2005. Print.

Herring, Phillip. Djuna: The Life and Work of Djuna Barnes. New York: Penguin, 1995. Print.

Hoeveler, Diane Long. Romantic Androgyny: The Women Within. University Park and London: The Pennsylvania State University Press, 1990. Print.

Jervis, John. Transgressing the Modern. Malden, MS: Blackwell Publications, 1999. Print.

McGavran, James Holt Jr. "Coleridge, the Wordsworths, and Androgyny: A Reading of 'The Nightingale'.” South Atlantic Review 53 (1988): 57-75. JSTOR. Web. 14 February 2011. 
Nancy, Jean-Luc. The Inoperative Community. Minneapolis: University of Minnesota Press, 2008. Print.

McNay, Lois. Foucault and Feminism: Power, Gender and the Self. Cornwall, UK: T.J. Press, 1992. Print.

Plato. The Symposium. Trans. Benjamin Jowett. Boston: Branden Press, 1996. Print.

Rogers, Katherine M. The Troublesome Helpmate: A History of Misogyny in Literature. Seattle and London: University of Washington Press, 1966. Print.

Sellers, Susan, Ed. The Hélène Cixous Reader. London: Routledge, 1994.

Shulkind, Jeanne, ed. Moments of Being: Unpublished Autobiographical Writings by Virginia Woolf. London: Chatto and Windus for Sussex University Press, 1976.

Smith, Victoria L. "A Story beside(s) Itself: The Language of Loss in Djuna Barnes's Nightwood." Modern Language Association 114.2 (1999):194-206. JSTOR. Web. 5 August 2011.

Smith-Rosenberg, Caroll. Disorderly Conduct: Visions of Gender in Victorian America. New York, NY: Alfred A. Knopf, 1985. Print.

Singer, June. Androgyny: Toward a New Theory of Sexuality. Garden City, New York: Anchor Press/Doubleday, 1977. Print.

Steinberg, Erwin R., ed. Stream of Consciousness Technique in the Modern Novel. Port Washington, NY and London: Kennikat Press, 1979. Print. 